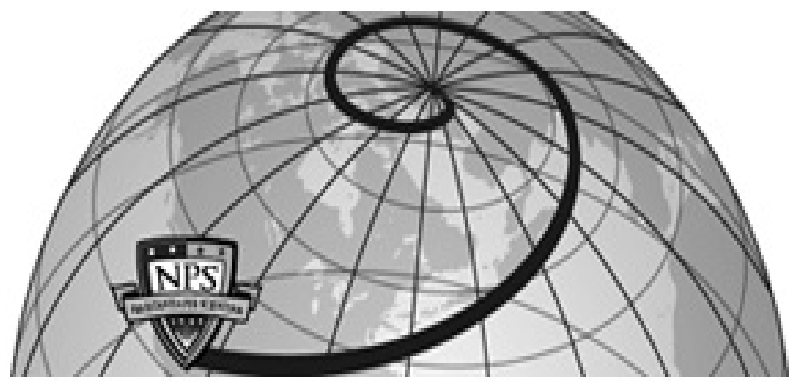

Calhoun: The NPS Institutional Archive DSpace Repository

Managing and improvising: lessons from jazz

Barrett, Frank J.

MCB University Press

Career Development International, v.3, no.7, 1998, pp. 283-286.

https://hdl.handle.net/10945/38011

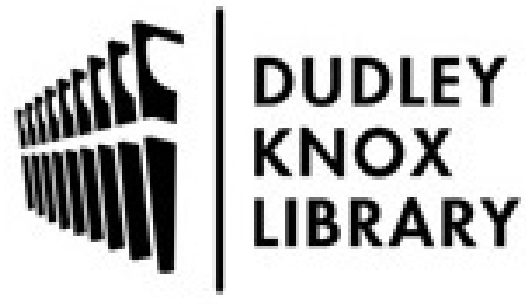

http://www.nps.edu/library
Calhoun is the Naval Postgraduate School's public access digital repository for research materials and institutional publications created by the NPS community. Calhoun is named for Professor of Mathematics Guy K. Calhoun, NPS's first appointed -- and published -- scholarly author.

Dudley Knox Library / Naval Postgraduate School 411 Dyer Road / 1 University Circle Monterey, California USA 93943 


\title{
Managing and improvising: lessons from jazz
}

\author{
Frank J. Barrett \\ Naval Postgraduate School, Monterey, California, USA
}

Offers a model of leadership development based on the metaphor of jazz improvisation. Examines the meaning of improvisation as applied to jazz and shows how managers' lives are similar to that faced by jazz improvisers in that they often face problems which are unstructured and ambiguous. Shows how the metaphor can be applied to other areas of organizational innovation.
Career Development

International

3/ 7 [ 1998] 283-286

(c) MCB University Press

[ISSN 1362-0436]
As wetransition from the industrial era to the knowledge era, we are faced with unprecedented challenges. If the post-industrial world has taught us anything, it is that we must be prepared for the unimaginable. We can barely keep up with the technological changes, the agility of new markets, radical new organizational designs. We know that we are called on to relate in new ways, to envision radical possibilities, to unlear $n$ many of the basic tenets of industrial management. Faced with the challenge of coor dinating diverse special ists to respond in novel ways to unprecedented problems, we are living in an organizational world that is making complex, often contradictory, demands. In what has been called the age of agi le giants, strategy for mulation and implementation must be virtually spontaneous rather than separate activities. As positional authority is eroding and giving way to knowledge authority, old command and control models of leadership devel opment are clearly inadequate for these ti mes. One model that might offer insight into the demands of the knowledge era is the jazz band (see Bar rett, 1998). The metaphor of jazz improvisation is one that has rich potential and impli cative resonance: managers often find themselves having to respond spontaneously to problems, to amend plans that are incomplete and hal for med anyway, to leap before looking and see where one's actions lead. Serendipity has become a legitimate source of learning, if not the norm.

The word "improvisation" derives from "improvisus", Latin for "not seen ahead of ti me". I mprovising involves playing extemporaneously, without a script. Music is composed and perfor med simultaneously with no rehearsal or chance to work out the ideas in advance. Playing on the spur of the moment means that good improvisers are risk takers. Improvisation is a treacher ous activity. There is always the possibility that one will makea mistake. Perhaps one will attempt to play a passage that is incoherent or beyond one's grasp; maybe one's ideas will not meld with others and will lead to collective chaos. In the meantime this risky activity occurs in front of a live audi ence. There are no second takes or chance to go back and revise what one attempted in or der to make it fit with others' playing. There is only the possibility of making use of whatever material is at hand at the moment. The art of improvisation is often the art of resourcefulness and bricolage - trying something out, seeing where it leads, and relating it to whatever elseis available.

J azz improvisation is an exhilarating adventure. Songs provides a minimal structure within which a great deal of spontaneous interaction occurs. What keeps the music from falling apart is the anticipation of future based on the inter pretation of past musical utterances. After hearing the previ ous notes and rhythms, players antici pate and guess what is about to happen: these projections become the frameworks that guide what choices to play next. In the meantime, at any moment players can introduce sur prising material that redirects the flow of the music. Within the limited impersonal rule-bound song conventions, there is a continual mutual adjustment and ongoing negotiation that keeps the music from becoming chaotic.

The notion, however, that improvisation involves pulling notes out of thin air, is misleading. In fact, the best players practice relentlessly so that they are prepared to be spontaneous. They imitate the master soloists, repeating patterns and phrases over and over until they become tacit and automatic. They call these patterns "licks", that is phrases they can rely on later when improvising. Although musicians practice playing patterns and "riffs", they cannot rely too heavily on these when they construct their solos. To do so would simply be repeating routines. The goal of improvisation is to create new music on the spot. For this reason, when musicians play well rehearsed patter ns or repeat their solos, they are looked down upon by other jazz players. There is a subtle but important line that players must guard against crossing. Certainly there are dangers inherent in the improviser's task, a temptation to play it safe, to play what is comfortable, known, and routine. But the best improvi sers challenge themsel ves to stretch outside of comfor table limits, to deli berately broaden their repertoire beyond what has become automatic. They practice in foreign keys, import different styles, experiment with odd rhythms all in the hope of discovering new 
Frank J. Barrett

Managing and improvising:

lessons from jazz

Career Development

International

$3 / 7$ [1998] 283-286 territory. This points to a paradox at the heart of improvisation. Players must learn various tools and patterns, but when the time comes to perform, they must find a way to let go and allow the music to take over.

One example of a jazz musician who knew about his temptation and stretched hi mself and his musi cians to abandon familiar routines to explore new ter ritory was Miles Davis. Davis took a very young band on the road in the mid-1960s - Herbie Hancock and Tony Williams were barely out of high school. Wayne Shorter and Ron Carter were new to the New York jazz scene. Yet when they went on the road to play to filled concert halls, he forbade the band to practice. He told them that he did not want them to "know" any songs too well, that they should do their practicing on the band stand. He wanted to eliminate habit and automaticity from their playing so that they would continue to befresh, to be on the edge of their learning capacity when it really counted - during the performance itself. This was a risky endeavor and was clearly a challenge for the young band. But his challenges did not stop there. Often in concert, Davis would call familiar songs in strange keys so that the musicians could not rely on lear ned finger patterns - they would have to think anew even if the "songs" themselves werefamiliar.

Davis practiced what I call provocative competence. He was able to inter rupt the players' routines and provide just enough structure to facilitate some brilliant performances. (In fact the live recordings of this band are some of the most revered in jazz history.) It is wor thwhile to look further into Davis' leader ship technique to glean what we can about possible lessons. What made his inter ruptions provocative rather than noxi ous? First is what I call affir mative competence (Barrett, 1995). Heheld an affir mative i mage of what these musicians were capable of. The young musi cians themselves were nervous no doubt and worried about what tricks Miles might pull next. But Davis had more confidencein their potential at that moment than they did themselves. If he had been worried about them making glaring er rors (which they occasionally did) he certainly would not have stretched them quite so much. Henever forgot what they were capable of, how they sounded when playing at their best. Second, the inter ruption was incremental. We know from creativity research that a modicum of anxiety boosts attention necessary for innovative breakthroughs, but excess anxi ety renders one i mmobile and hel pless. Davis' incremental inter ruption introduced just enough anxi ety to facili tate creative breakthroughs. There was enough familiarity in the situation so that the musicians had some reliable structures to draw on. They knew, for example, the basic structure of the song even if the context was now foreign. If the inter ruption was too large it would have caused excess anxi ety and blocked creativity. Thi rd, it is useful to look at what happens after the inter ruption. The music does not just stop, waiting for someone to do something. That too would have raised excess anxi ety. Rather there was a temporal structure in place that invited continual activity. The song provided non-negotiable minimal constraints through time. In a sense, it provided a "running start": they did not have to create a brand new context, they could join one in progress. There were no interpersonal negotiati ons necessary to decide what to do next. The song provided a vehicle for collective movement through time, like a train leaving the station, inviting the members to get on board. They knew that they had to take action even if they were not completely sure where the musi c would lead.

\section{Implications for managers}

Managers' lives are similar in many ways to those of jazz musicians. Managers often face problems that are unstructured and ambiguous. They have to inter pret vague cues and devise novel responses which they had no time to rehearse. In many circumstances they find themselves jumping in and acting without a plan or a guarantee of where actions will lead. What can be lear ned from jazz improvisation that we can apply to other areas of organi zational innovation?

\section{"Baptism by fire" can be a rich teacher} For jazz musicians, the more patterns and "licks" that one has under one's belt, the wider the repertoi re of possible responses when novelty is demanded. Since musicians improvise by building up a repertoire of multiple experiences and a myriad of styles, it might be useful for organizations to prepare managers for improvisation by increasing their range of experiences so that they have more knowledge resources to draw on. Managers too often find themselves responding in old ways to new situations, unable to imagine other responses because they have not been exposed to wider experiences. This has implications for career development. Many organizations have practiced some for $m$ of job rotation. However, the lessons of jazz might suggest that we expand this even further, to encourage employees to experiment with radically different contexts that are challenging and distant from familiar domains, much 
Frank J. Barrett

Managing and improvising:

lessons from jazz

Career Development

International

3/ 7 [1998] 283-286
likeStan Getz practicing Brazillian music, Chick Corea studying Bela Bartok, or J ohn Coltrane studying Indian modes. Rather than wait until people are prepared to embark on new, challenging experiences, there is something to be said for throwing someone into a situation simply in order to widen his/ her experiential reper toire for the mere practice of experiencing another perspective. Universities often espouse this practice in thei $r$ sabbatical policies. They encourage faculty to embark on an entirely different path, to learn an entirely new body of knowledge in order to refresh themselves, to guard against the temptati on to become stale and lose the fire of curiosity that should mark a field of inquiry. Perhaps organizations could experiment with the idea of giving employees experi ences in fields far adrift from their area of expertise as an investment in the employees' capacity for fresh inquiry. Such building up of various resources might pay off later when members need to fashion fresh responses and spawn novel ideas.

Increase the processing of information when employees are taking action J azz musicians have few reliable guides for determining the future selection of notes. What is essential to their note selection is how they have made sense of the past enactments. Often we articulate justifications and rationales retrospectively in an attempt to convince ourselves and others that whatever has happened was the intended plan. We often organize as if we are rational planners and strategic willful decision makers, but more often than not we are more likejazz players who make sense of action after it has occurred. However, if we take seriously the notion of retrospective sense making, we would provide more forums for individuals and groups to process infor mation within close proximity to the acts taken. This would imply that it would benefit organizations to facilitate for ums in which members can make sense of action while it is taking place or soon after. This is the agenda behind the US Army's after-action reviews. This learning experiment aims to bring together all of the players in a field exercise immediately afterwards to process what each of the members experienced and learned from various perspectives. The aim is to boost collective sense making and give those who did not experience a certain facet of the exercise a vicarious learning experience as lessons are gl eaned and captured. Perhaps organizations could deliberately plan for activities that often happen informally and haphazardly - people gathering and exchanging vi ews after significant actions and initiatives. Creating something like "after action reviews" is akin to providing some post facto structure to an improvised solo, and offers the oppor tunity for members to consi der a variety of inter pretations.

\section{Take advantage of errors as a source of} learning

Some of the best jazz solos were inspired by, or began with, mistakes of various kinds. What jazz musi cians often do when they make er rors is repeat them, amplify them, embellish them so that they sound intentional and coherent. J ust as jazz musicians must make the most of whatever material they have before them, including the inevi table mistakes that happen from time to time, organizations would do well to value errors as a source of learning rather than an occasion for punishment. To punish errors is to squash experimentation. Organizations such as 3M have known for years that mistakes are often the inspiration for radical innovations. Also, recent studies of health care teams reveal that those teams that openly talk about mistakes rather than hide them, find ways to improve thei $r$ processes and are actually much safer than those teams that punish mistakes and do not encourage open discussion.

Value appreciation as a mode of knowing When jazz players are improvising, they can never know for sure what their colleagues will play. They have to respond to the enactments they hear as they are happening. Every utter ance and enactment is a candi date for departure and development of an inspiring solo. Charlie Parker was inspired by every sound he heard while soloing, even the sound of car horns and bottles shattering. This implies that musi cians approach such enactments appreciatively. Rather than criticize, judge, or fix what they have heard, they simply assume that whatever is happening is good and has potential. In order for the band to work well together and support one another's soloing, they assume that every utter ance makes sense and is leading somewhere sensible. Recent research in the area of lear ning and imagery for mation supports this notion that one lear ns better when focusing on success then when trying to repair failures. I magi ne organizations adapting an ethos that cel ebrates those moments when people are operating at thei $r$ best and attempts to maximize those moments rather than solving problems in order to re-establish the status quo. Organizations that adapt appreci ative learning cultures (Barrett, 1995) and organizations that initiate appreciative inquiry as ground for 
Frank J. Barrett

Managing and improvising:

lessons from jazz

Career Development

International

$3 / 7$ [1998] 283-286 innovati on (Cooper rider and Srivastva, 1987) have discovered that an approach focused on solving existing problems is limited in forging visions of possibility.

Enliven the sense of play

A sense of play is necessary to enhance the openness, receptivity, and fluid coordination that occurs when jazz players "strike a groove" with one another. Too much seriousness and too much deliber ate willfullness inhibits play. When engaged in play, members are more likely to "let go", to suspend conscious thinking, to give up control in a way that allows them to achi eve a deeper synergistic connection. Often musicians immersed in this kind of play find themselves playing beyond their previously imagi ned capacity. Organi zations might benefit by setting aside contexts that legitimize play as a fruitful, meaningful activity, one that might enhance the sheer joy of relational achievement.

\section{Cultivate leadership that practices provocative competence}

The example of Miles Davis interrupting his young musicians' comfortable routines and provoking them to new areas of discovery is inspiring and a rich illustration of the role of leader as facilitator of learning. Leadership involves an affirmative capacity to deli berately notice and focus on members' strengths, even when the members themselves have lost sight of their capacities. In this sense, leadership involves keeping hopealive. This is not to say that leadership behavior is always welcomed by those who are the reci pi ents of these gestures. I imagi ne that backstage, the young players spoke of Davis' tinkering in less than glowing ter ms. Some might have found him irritating. In a sense he used trickery to draw out their skills. Such a leadership capacity, in the wrong hands, could easily be seen as manipulative or even tyrannical.
However, when leaders are abl e to provide a holding environment that provides enough safety for members to move away from familiar responses and explore the unknown, chances for new discovery and innovation are increased.

\section{Conclusion}

In a post-industrial, gl obal economy, managers face increasingly complex environments, dealing with ambiguous infor mation and unanalyzable tasks. With such incomplete knowledge and inferior plans, they must take action anyway. They must learn to facilitate and attend to unfolding agreements as groups coal esce and disassemble. Managers conti nually find themselves at the edge of their competency. In such a context not to take a risk is risky behavior. J azz i mprovisation offers some lessons. As a metaphor, it legitimates unconventional experimentation, serendi pi ty as a source of learning, resourcefulness as a critical resource, and error-making as indispensable to the creative process. In a world in which yester day's responses become inappropriate maps for today's challenges, managers must improvise and would do well to pay attenti on to what jazz musicians are doing.

\section{References}

Barrett, F.J . (1995), “Creating appreciative learning cultures", Organization Dynamics, Vol. 24 No. 1, Fall, pp. 36-49.

Bar rett, F.J . (1998), “Creativity and improvisation in jazz and organizations: implications for organizational learning", Organization Science, Vol. 9 No. 5, Fall.

Cooper rider, D. and Srivastva, S. (1987), "Appreciative inquiry in organizational life", in Woodman and Passmore, Research in Organizational Changeand Devel opment, Vol. 1, pp. $129-70$. 